\title{
SELECTED INSTRUMENTS OF COLLECTIVE LABOUR LAW IN THE LIGHT OF THE EUROPEAN SOCIAL CHARTER (REVISED), THE EU CHARTER OF FUNDAMENTAL RIGHTS, THE ILO CONVENTIONS AND THE EUROPEAN PILLAR OF SOCIAL RIGHTS
}

\begin{abstract}
The European Social Charter, the EU Charter of Fundamental Rights and the European Pillar of Social Rights, are tied by mutual interactions and inspirations. The aim of this study is to present the institution of solidarity action, lockout and protection of workers' elected representatives, and reflection on which instruments of international law can be applied in these areas.
\end{abstract}

Słowa kluczowe: Europejska Karta Społeczna, Karta Praw Podstawowych UE, Europejski Filar Praw Społecznych, strajk, lokaut, reprezentacja pracowników

Keywords: The European Social Charter, EU Charter of Fundamental Rights, European Pillar of Social Rights, strike, lockout, workers' representative

ASJC: 3308, JEL: K31

\section{Introduction}

The European Social Charter (hereinafter referred to as: "ESC"), the EU Charter of Fundamental Rights (hereinafter referred to as: "CFREU") and the European Pillar of Social Rights (hereinafter referred to as: "EPSR"), despite the significant differences related to their position in the multicentric legal order of the European countries, are tied by mutual interactions and inspirations. It also applies to social rights related to conducting social dialogue, such as freedom of association in trade unions and employers' organisations, the right to bargain collectively, the right to conduct collective disputes and the right of workers to information and consultation.

The social dialogue and participation of workers are among the principles set out in the European Pillar of Social Rights. The European Commission also refers to social 
dialogue at the European level as one of the mechanisms by which the principles of the Pillar can be implemented, declaring support for the resumption of social dialogue at the European level and emphasising the role of dialogue between employers' and employees' organisations (Commission Staff Working Document: $\{\mathrm{COM}(2017) 250$ final $\}$ \{SWD(2017) 200 final $\{$ SWD(2017) 206 final $\}$ ).

The aim of this study is to present how three selected institutions of collective labour law, the application of which may raise doubts in the Polish collective labour law (solidarity action, lockout and protection of workers' ad hoc representatives), can be on the ground of international law and the European Pillar of Social Rights.

\section{Solidarity action}

A solidarity action [strajk solidarnościowy] can take two forms: a subsidiary strike [strajk akcesoryjny] (organised to support the demands of workers who themselves are on strike) and a defensive or substitute strike [strajk defensywny/zastępczy] (organised to support the demands of workers of another workplace who are not entitled to strike). Art. 22 of the act on resolution of collective labour disputes (the Act of 23 May 1991, Dz.U. 2019, item 174 consolidated text) refers to the solidarity defensive strike.

Given that the organisation of a subsidiary strike is not explicitly prohibited by the law, in should be considered admissible, especially in a situation where workers undertaking such an action have an indirect and economic interest in the primary strike. In particular, restrictions on the solidarity action covering employers belonging to a group of undertakings should be considered unjustified (Oniszczuk 2014, pp. 757 ff). Additional arguments for the admissibility of the right to subsidiary strike are provided by instruments of international law and their interpretations issued by international bodies.

In the Council of Europe's human rights protection system, the right to collective action is explicitly mentioned in Art. 6(4) of the ESC of 1961 and the Revised European Social Charter. Under the European Social Charter, a solidarity action should be considered admissible, since such collective actions in fact relate to conflicts between employees and the employer. Especially that, as F. Dorssemont underlines, the provisions of Art. 6(4) ESC do not refer in any way to the relationship between employees and their employer (Dorssemont 2017, p. 276; an opposite opinions: Świątkowski 2007, pp. 227-228; Mikkola 2010, p. 283; see also: ESCR Conclusions...).

The right to strike is also recognised by the International Labour Organization (see more: Paździor 2002, pp. 45-52; Novitz 2003, pp. 89-125; Świątkowski 2008, pp. 44 ff). Even though the Convention No. 87 does not explicitly regulate the right to strike, ${ }^{1}$ at

1 The right to strike appears occasionally in ILO Conventions and Recommendations, e.g. in Art. 1 of Convention No. 105, Dz.U. of 14 July 1959, No. 39, item 240, which prohibited the use of forced or compulsory labour as penalties for participation in strikes, as well as in Convention no. 92, not ratified by Poland (Gernigon, Odero, Guido 1998, p. 7). 
the second meeting in 1952, the Committee on Freedom of Association (CFA) recognised the right to strike as an inseparable consequence of the right of coalition protected by Convention No. 87 (International Labour Office 2018, pp. 146-147). The CFA's position on the admissibility of a solidarity action is clear: A general prohibition of sympathy strikes is a violation of workers' rights, as is the ban on solidarity actions within complex enterprises (International Labour Office 2018, p. 146). The ILO Committee of Experts on the application of the conventions and recommendations (ILO-CEACR) of 2012 confirmed the need to protect workers' rights to industrial action in matters concerning them, although in some cases a direct employer may not be a party to the dispute. The Committee recalled that workers should be able to stage sympathy strikes provided that the initial strike that they are supporting is itself lawful. and participate in solidarity actions, provided the initial strike they are supporting is itself lawful (Report of the Committee...).

References to the case-law of the European Committee on Social Rights and the ILO can be seen also in the decisions of the ECHR, especially in Enerji Yapi-Yol Sen v. Turkey (judgment of the ECHR of 21 April 2009, application no. 68959/01) and also in the case of the Croatian trade union of medical workers (Hrvatski liječnički sindikat; judgment of the ECHR of 27 November 2014, application no. 36701/09).

However, in the RMT case, the ECHR emphasised that as regards the right to strike, "regard must be had to the fair balance to be struck between the competing interests of the individual and of the community as a whole," which means that the legislature of the state-party to the Convention, may apply a margin of appreciation than (see: judgment of the ECHR of 8 September 2014, application no. 31045/10, par. 86 of the operative part of the judgment). This margin will be lesser in the case of direct industrial action directed against the employer covered by the collective dispute, and in the case of solidarity action - wider (judgment of the ECHR of 8 September 2014, application no. $31045 / 10$, par. 88,99 of the operative part of the judgment).

Art. 28 of the CFREU guarantees to workers and employers, or their respective organisations, in accordance with Union law and national laws and practices, the right to negotiate and conclude collective agreements at the appropriate levels and, in cases of conflicts of interest, to take collective action to defend their interests, including strike action. The explanations relating to the Charter of Fundamental Rights (Explanations of the Praesidium...) emphasised that the right of collective action was recognised by the European Court of Human Rights as one of the elements of trade union rights laid down by Art. 11 of the ECHR. The modalities and limits for the exercise of collective action, including strike action, come under national laws and practices, including the question of whether it may be carried out in parallel in several Member States.

The right to take collective action, and thus not only a strike but also other forms of protest, such as pickets, was limited, however, only to "conflicts of interest" that is aspirations to shape the situation of workers. The Charter does not relate to rights disputes, e.g. regarding the interpretation of labour law (Mitrus 2013). Member States may also impose restrictions on the right to strike. 
The case law of the CJEU in this area is also interesting. In Viking (judgment of the CJEU of 11 December 2007, C-438/05) and Laval (judgment of the CJEU of 18 December 2007, C-341/05) issued before the entry into force of the Lisbon Treaty, the Court recognised the right to take collective action as a general principle of EU labour law. This opinion was not limited to only one type of collective action (strike), so it should be assumed that it covered various types of action, including a solidarity action, especially since in both cases collective actions (call for boycott-Viking-and blockade of the construction site-Laval) had a solidarity character (Dorssemont, Rocca 2019, pp. 489-490).

Admissibility of sympathy action stems not only from the in dubio pro libertate interpretation of the national law, but also from the international law.

\section{Lockout}

The right to lockout is usually discussed in the context of the principle of equality and balance between the parties of the employment relationship, as means of balancing workers' right to strike, in particular in the event of an illegal strike (Cudowski 2006, p. 497; Świątkowski 2008, p. 37). The fact that both social partners have measures to exert pressure during the process of collective bargaining is also presented as a manifestation of the autonomy of social partners (Świątkowski 2008, p. 32).

The lockout has not been regulated explicitly in the Polish labour law. ${ }^{2}$ Just like the right to strike, the right of employers and their organisations to lockout is not explicitly regulated in the ILO Conventions, however it is derived from Art. 3 of ILO Convention No. 87 (Cudowski 2006, p. 496) As mentioned above, both the UE Charter of Fundamental Rights (Art. 28) and the European Social Charter (Art. 6(4)) ${ }^{3}$ refer to the right of workers and employers and their representatives to collective actions. For employers or their organisations, the equivalent of strike is a lockout-an institution that raises considerable controversy among labour law scholars. The European Committee of Social Rights (ECSR) took it for granted that under the European Social Charter, both the right of employees to collective action (which means not only strike but also other protest actions), but also the right of employers to lockout is protected (Baran 2010, p. 715; Matey-Tyrowicz 2006, p. 63; Skąpski 2014, p. 834). The ECSR does not deem it necessary for the lockout to be regulated directly by law. It is sufficient if the conditions

2 The legislature recognises the existence of this institution. The reference to the lockout can be found in Art. 165 (2)(8) of the act of 18 September 2001-Maritime Code, where the legislature formulates the norm according to which the carrier is free from liability, if the damage occurred as a result of lockout (possibly a strike or other circumstances suspending or hampering work completely or partially). See: Witkowski 2014, pp. 239-252.

${ }^{3}$ Cudowski (2006, p. 496) notes, however, that it was the right to lockout that determined Poland's refusal to ratify this provision. 
for lockout are determined by the practice of social partners and court rulings, and this right is not excessively restricted.

According to A.M. Świątkowski, within the common market social partners enjoy the freedom to organise industrial actions to protect their interests, which is not restricted by EU regulations, as demonstrated by the rulings of the CJEU, including in cases Laval and Viking (Świątkowski 2013, p. 128). The EU Charter of Fundamental Rights therefore strengthens the arguments of the lockout supporters, in particular as a response to the announced illegal strike, and national legislature has a wide margin of appreciation as to the introduction of appropriate solutions at the national level (Świątkowski 1996, pp. $31 \mathrm{ff}$; Mitrus 2013, commentary on Art. 28).

\section{Protection of ad hoc representatives}

Workers' representatives selected in the in the standard manner adopted by the employer usually function as a substitute form of representation of workers' rights and interests, subsidiary to trade unions (Stelina 2007, p. 97; as regards the relations of trade union and non-trade union representative bodies, see: Stelina 2012, pp. $170 \mathrm{ff}, 327 \mathrm{ff})$. The group of $a d$ hoc representatives of workers is very diverse and heterogeneous, regulated in various provisions in case by case basis.

Workers' representatives within the meaning of ILO Convention No. 135 in addition to trade union representatives include elected representatives, namely, representatives who are freely elected by the workers of the undertaking in accordance with provisions of national laws or regulations of collective agreements and whose functions do not include activities which are recognised as the exclusive prerogative of trade unions in the country concerned (Art. 3 (b) of the ILO Convention No. 135). The content of the ILO Convention No. 135 becomes of special significance as the Explanatory Report to the European Social Charter (Revised) explicitly refers to ILO Convention No. 135 as a source of inspiration for Art. 28 ESC (Revised) and explains that examples of facilities to be granted to workers' representatives may be found in ILO Recommendation No. 143 of 1971. Definition of workers' representatives under the Art. 28 ESC (Revised) is even broader than in Convention No. 135, as it provides, in accordance with Part II of the Appendix to the ESC (R), that "workers' representatives" should be understood as persons who have been recognised as such in accordance with national law or practice. In the 2014 Conclusions on Austria (European Committee of Social Rights, Conclusions on Austria, 5 December 2014, 2014/def/AUT/28/EN), Malta (European Committee of Social Rights, Conclusions on Malta, 5 December 2014, 2014/def/MLT/28/ EN) and the Netherlands (European Committee of Social Rights, Conclusions on the Netherlands, 5 December 2014, 2014/def/NLD/28/EN), the ESC (Revised) gives examples of workers' representatives who may function alongside or instead of trade unions (e.g. workers' commissioner, works councils, workers' representative on the supervisory board). The term "workers' representation" has no autonomous international 
definition and covers only those entities which are recognised as such under national law (Świątkowski 2006, p. 366). Under Polish law, this broad definition would cover all ad hoc representatives, because despite clear inspiration by ILO regulations, Art. 28 ESC (Revised), unlike ILO Convention No. 135, does not apply only to elected representatives (Brunn 2017, pp. 468-470).

This distinction is important. According to the Art. 59(4) of the Polish Constitution the scope of protection of the freedom of association, the right to bargain collectively and to conduct strikes and other forms of protest by trade unions was determined not only by ratified but all signed international agreements. However, the rights of ad hoc workers' representatives go beyond the provisions of Art. 59(1-3) of the Polish Constitution. This means that only the ratification of the European Social Charter (Revised), of course including Art. 28 would ensure full protection for all workers' representatives in the Polish legal system. According to Art. 4 of ILO Convention No. 135, the national legislation may specify the category or categories of workers' representatives who are entitled to the protection and facilities provided for in this Convention. In the Polish legal system, this protection was granted to institutional representations such as works councils, European works councils, works councils of a state-owned enterprise, not ad hoc representatives (Baran 2014, pp. 916-918). This problem is all the more important because, as noted by Monika Latos-Miłkowska, the legislator on the one hand grants more and more rights to representatives appointed $a d h o c$, and on the other hand, without granting any protection or facilitation in the laws, usually does not specify any criteria for how they should be selected. As a result, these entities are too weak to have a real dialogue with the employer, and their mandate to represent employees can be questioned (Latos-Miłkowska 2014, p. 105; see also: Gładoch 2005, p. 201; Rycak 2010, pp. 162-164).

\section{European Pillar of Social Rights}

First of all, it has to be underlined that the European Pillar of Social Rights is not a legal act or a binding catalogue of rights, but rather a set of principles that are designed to lead to the development of legislative and political initiatives at EU and Member State level. Proclamation of the Pillar made the social rights to be taken into account more systematically in EU social and economic governance (De Schutter 2018, p. 47). It is then worthwhile to reflect if the text of the Pillar itself as well as its implementation instruments can reinforce collective labour law institutions on the EU and in consequence national level.

The authors of the European Pillar of Social Rights draw inspiration from international law in the social sphere. At the same time, the very way in which Principle 8 of the Pillar is expressed may raise doubts. Comparing the wording of Principle 8 to the relevant provisions of the EU Charter of Fundamental Rights and the European Social Charter, it can easily be seen that the Pillar does not develop or strengthen any of the rights contained therein. 
First of all, the text of the Pillar lacks any reference to freedom of association as a condition for social dialogue. Admittedly, the explanations to the Pillar (Commission Staff Working Document: $\{\mathrm{COM}(2017) 250$ final $\}\{$ SWD(2017) 200 final $\}$ SWD(2017) 206 final $\}$ ) refer to Art. 28 of the CFREU and also Art. 151 of the Treaty on the Functioning of the European Union regarding the promotion of dialogue between social partners, but references to the European Social Charter and the ILO Conventions on freedom of association, such as Conventions 87, 98 and 151 (Lörcher, Schömann 2016, p. 68), have been omitted. This way of formulating both the text of the proclamation and explanations may suggest that taking further actions to implement the freedom of coalition is not necessary.

The fragment on collective bargaining provides that social partners "shall be encouraged" to negotiate and conclude collective agreements. However, this is not tantamount to the right to conduct such bargaining. Only in respect of workers' information and consultation the phrase "workers or their representatives" was used. However, the "support for increased capacity of social partners to promote social dialogue" may on the one hand relate to social dialogue at every level, and on the other hand the declared "support" seems to be related to the process of conducting the dialogue, and not its results in the form of collective agreements.

The text of the Pillar also omits the right to strike guaranteed in both Art. 28 of the CFREU and Art. 6 of the ESC. It includes only a much more general guarantee of respect for the "right to take collective action", which does not seem to encourage the implementation of those instruments of international law that guarantee the right to strike to employees directly (like the EU Charter of Fundamental Rights and ESC) or indirectly through interpretations issued by judicial bodies as is the case with ILO or ECHR.

Principle 8 of the Pillar regarding social dialogue in the third sentence refers to the right of workers or their representatives to be informed and consulted in good time on matters relevant to them. The examples of the areas of information and consultation given in this paragraph (in relation to transfers, restructuring and merger of undertakings, as well as collective redundancies) bring to mind both institutional representation existing in the Polish legal system and ad hoc workers' representatives (e.g. as part of collective redundancies). In addition, the activities of ad hoc representatives also cover issues that are reflected in other Pillar principles, such as for example Principle 5-secure and adaptable employment, Principle 7-information about employment conditions and protection in case of dismissals, Principle 10-healthy, safe and well-adapted work environment and data protection. This could open discussion on the status of this category of workers' representatives.

However, the potential for strengthening workers' representation (not just trade unions) is not sufficiently used. The working document accompanying the Pillar defines the role of social partners in a fairly general and schematic way (Commission Staff Working Document: $\{\mathrm{COM}(2017) 250$ final $\}\{$ SWD(2017) 200 final $\}\{$ SWD(2017) 206 final\}). These references come down to four "formulas" describing social partner's activities on each level (wider in: Unterschütz 2019). In fact activities undertaken by the 
social partners depend on their initiative and can hardly be attributed to the content of the working document presented above.

The European Pillar of Social Rights is accompanied by the Social Scoreboard designed to monitor the implementation of the Pillar principles by tracking trends and results in EU countries in 12 areas divided into three categories: equal opportunities and access to the labour market, fair working conditions and social protection and inclusion. The Social Scoreboard was presented for the first time in April 2017, and then in March 2018 in the joint employment report (Joint Employment Report...). It is intended to contribute to the European Semester of economic policy coordination, serving to assess social policy progress (Monitoring EU Member...). The intention of the authors is that the social scoreboard should also detect key employment and social problems and assess convergence or divergence patterns between Member States (see: The Social Scoreboard). The scoreboards from 2017 and 2018 completely omitted the indicators related to conducting social dialogue, although some of the principles can and should finally be implemented through agreements concluded at the appropriate level-the workplace or industry — and in practice are subject to collective bargaining. These include in particular: principle 1-education, training and life-long learning; principle 2-gender equality; principle 3-equal opportunities; principle 4-active support to employment; principle 7-information about employment conditions and protection in case of dismissals; principle 9-work-life balance and principle 10 concerning healthy and safe working conditions. Omitting these aspects of social dialogue means that monitoring the implementation of principle 8 on social dialogue is at least significantly hindered. It should not be expected that implementation of the European Pillar of Social Rights will contribute to solving the problems around solidarity strikes, lockout and non-union workers' representatives in Poland.

\section{Concluding remarks}

Despite some similarities in the way workers' collective rights are formulated, it can be seen that European Social Charter (Revised) provides a broadest protection for the collective workers' rights than the EU Charter of Fundamental Rights.

In case of solidarity action the provisions of the EU Charter of Fundamental Rights and the European Social Charter (Revised) provide arguments for a broader application of the solidarity action than this specified in the act on resolution of collective disputes and additional arguments for the admissibility of the right to subsidiary strike are provided by instruments of international law and their interpretations issued by international bodies. Given that the legislator does not explicitly prohibit the organisation of a subsidiary strike, in accordance with the in dubio pro libertate principle, the conduct of a subsidiary strike should be regarded as admissible, especially in a situation where employees undertaking such an action have an indirect and economic interest in the primary strike. In consequence, the application of restrictions 
on the solidarity action in the case of employers belonging to a group of undertakings should be considered unjustified (Oniszczuk 2014, pp. 757 ff). It is doubtful that the Pillar of Social Rights could contribute to changing national regulations, because as mentioned in the introduction the issue of strike was completely omitted in Principle 8 of the Pillar.

As far as the lockout is concerned wording of Art. 6 of the ESC and Art. 28 of the CFREU provide an argument for regulating the conditions of carrying out lockouts by employers (according to Cudowski 2006, p. 496, it was the right to lockout that determined Poland's refusal to ratify this provision ). The draft Collective Labour Code of 2008 included such a proposal. However, in the draft Collective Labour Code of 2018, this institution was not regulated. It is therefore doubtful whether the legislature intends to introduce regulations regarding this institution in the future. Given the way Principle 8 of the EPSR is formulated means that this instrument is not likely to change the national legislation on lockout.

The EU Charter of Fundamental Rights provides additional arguments for granting protection and facilities to $a d$ hoc workers' representatives. Even if there is no equivalent of Art. 28 of the ESC (Revised), however, some provisions should be interpreted in the light of Art. 28 of the ESC (Revised). These include Art. 21 (non-discrimination), Art. 27 (right to information and consultation) and Art. 30 (protection in the event of unjustified dismissal; Brunn 2017, p. 476). Also in this area, it is hard to expect that the Pillar of Social Rights will give hope for new initiatives affecting the shape of national regulations, although the wide range of rights granted to workers' representatives elected ad hoc encourages further reflection. Also on the basis of the working document illustrating the implementation of the Pillar principles, it can be argued that the initiatives taken under the above-mentioned principles most likely will not contribute to the protection and facilitation of workers' representatives appointed ad hoc (Commission Staff Working Document: $\{\mathrm{COM}(2018) 130$ final $\})$.

As far as implementation of the Pillar is concerned, reference to social dialogue in national recommendations for Poland, the is quite general (Commission Staff Working Document: $\{\mathrm{COM}(2018) 120$ final $\})$. The authors of the document point out that the Social Dialogue Council does not receive all important draft laws (e.g., such as the amendment to the law abolishing the upper limit of social security contributions), although it conducted intensive work in several policy areas. It is also stated that Poland has one of the lowest rates of collective bargaining coverage in the Member States, and wage negotiations are hardly coordinated at all, as they take place mostly at company level.

However, in the Report planned for 2019, introduces changes that strengthen the voice of social partners. There is more room for social dialogue, and a reference to the ability of social partners to act, illustrated by the indicator of unionisation in individual EU countries. The authors rightly point out that the unionisation rate alone does not necessarily determine the actual strength and participation of trade unions, giving the example of France, where relatively few trade union organisations enjoy broader public support (Draft Joint...). The authors of the report also note the impact 
of new forms of work organisation on the level of unionisation as well as initiatives taken by trade unions for employees of digital platforms and recruitment of members among young people (Joint Employment Report..., p. 73). Nevertheless, the possible influence of the EPSL on presented institutions of collective labour law in Poland is rather weak.

\section{References}

Baran K. W. (2010) Podstawowe zasady zbiorowego prawa pracy [The fundamental principles of collective labour law] [in:] K. W. Baran (red.), Zarys systemu prawa pracy [An outline of labour law system], t. 1: Część ogólna prawa pracy [General part of labour law], Warszawa.

Baran K. W. (2014) Status prawny przedstawicieli pracowników [Legal status of workers' representatives] [in:] K. W. Baran (red.), System prawa pracy [The system of labour law], t. 5: Zbiorowe prawo pracy [Collective labour law], Warszawa.

Brunn N. (2017) Article 28: The Right of Worker's Representatives to Protection in the Undertaking and Facilities to be Accorded to Them [in:] N. Bruun. K. Lörcher, I. Schömann, S. Clauwaert (eds.), The European Social Charter and the Employment Relations, Oxford-Portland (Oregon).

Cudowski B. (2006) Spory zbiorowe [Collective labour disputes] [in:] M. Matey-Tyrowicz, T. Zieliński (red.), Prawo pracy RP w obliczu przemian [Labour law of the Republic of Poland in the era of transformations], Warszawa.

Dorssemont F. (2017) The Right to Bargain Collectively [in:] N. Bruun, K. Lörcher, I. Shömann, S. Clauwaert (eds.), The European Social Charter and the Employment Relation, Oxford-Portland (Oregon).

Dorssemont F., Rocca M. (2019) Article 28: Right of Collective Bargaining and Action [in:] F. Dorssemont, K. Lörcher, S. Clauwaert, M. Schmitt (eds.), The Charter of Fundamental Rights of the European Union and the Employment Relation, Oxford-Portland (Oregon). Gernigon B., Odero A., Guido H. (1998) ILO Principles Concerning the Right to Strike, Geneva. Gładoch M. (2005) Uczestnictwo pracowników w zarządzaniu przedsiębiorstwem w Polsce. Problemy teorii i praktyki na tle prawa wspólnotowego [Employee participation in company management in Poland. Theory and practice in the context of Community law], Torun.

Latos-Miłkowska M. (2014) Pozazwiazkowe przedstawicielstwa pracownicze [in:] J. Stelina (red.), Zakładowy dialog społeczny, Warszawa.

Lörcher K., Schömann I. (2016) The European Pillar of Social Rights: Critical Legal Analysis and Proposals, ETUI Brussels.

Matey-Tyrowicz M. (2006) Podstawowe prawa społeczne w dziedzinie pracy jako „mega-źródła” prawa pracy [Fundamental social rights as "mega-sources" of labour law] [in:] M. Matey-Tyrowicz, T. Zieliński (red.), Prawo pracy RP w obliczu przemian [Labour law of the Republic of Poland in the era of transformations], Warszawa.

Mikkola M. (2010) Social Human Rights of Europe, Porvoo. 
Mitrus L. (2013) [in:] A. Wróbel (red.), Karta Praw Podstawowych Unii Europejskiej. Komentarz [Charter of Fundamental Rights of the European Union. Commentary], Legalis.

Novitz T. (2003) International and European Protection of the Right to Strike, Oxford.

Oniszczuk J. (2014) Spory zbiorowe [Collective labour disputes] [in:] K. W. Baran (red.), System prawa pracy [The system of labour law], t. 5: Zbiorowe prawo pracy [Collective labour law], Warszawa.

Paździor B. (2002) Strajk w orzecznictwie organów kontrolnych Międzynarodowej Organizacji Pracy [Strike in the case law of the control bodies of the International Labour Organization], "Państwo i Prawo," nr 1.

Rycak M. B. (2010) Szczególna ochrona trwałości stosunku pracy przedstawicieli pracowników [Special protection of stability of employment relationship of workers' representatives] [in:] J. Wratny (red.), Związki zawodowe a niezwiązkowe przedstawicielstwa pracownicze: $w$ gospodarce posttransformacyjnej [Trade unions and non-union workers' representation: in the post-transformation economy], Warszawa.

Skąpski M. (2014) Lokaut [Lockout] [in:] K. W. Baran (red.), System prawa pracy [The system of labour law], t. 5: Zbiorowe prawo pracy [Collective labour law], Warszawa.

Smusz-Kulesza M. (2012) Konkurencja uprawnień informacyjnych realizowanych przez zwiazkowe $i$ niezwiąkowe przedstawicielstwa pracownicze [Competition of rights to information exercised by trade union and non-union employee representative bodies] [in:] Z. Hajn (red.), Związkowe przedstawicielstwo pracowników zakładu pracy [Trade union representation of employees], Warszawa.

Stelina J. (2007) Zbiorowa reprezentacja pracowników w Polsce - stan obecny i perspektywy [Collective representation of workers in Poland: Current situation and perspectives] [in:] A. Kubicka (red.), Problemy kodyfikacji prawa pracy. Wybrane zagadnienia zabezpieczenia społecznego: referaty na XVI Zjazd Katedr oraz Zakładów Prawa Pracy i Ubezpieczeń Społecznych Gdańsk, 19-21 września 2007 roku [Problems of codification of labour law. Selected social security issues: Papers for the $16^{\text {th }}$ Congress of Departments and Labour Law and Social Insurance Departments Gdańsk, 19-21 September 2007], Gdańsk.

Stelina J. (2012) Związki zawodowe a pozazwiązkowe przedstawicielstwo pracowników w zakładzie pracy [Trade unions and non-union representation of workers in the workplace] [in:] Z. Hajn (red.), Związkowe przedstawicielstwo pracowników zakładu pracy [Trade union representation of employees], Warszawa.

Świątkowski A. M. (1996) Lokaut (studium stosunków przemysłowych) [Lockout: A study of industrial relations], "Studia z Zakresu Prawa Pracy i Polityki Społecznej."

Świątkowski A. M. (2006) Karta Praw Społecznych Rady Europy [Charter of Social Rights of the Council of Europe], Warszawa.

Świątkowski A. M. (2007) Charter of Social Rights of the Council of Europe, Alphen aan den Rijn. Świątkowski A. M. (2008) Międzynarodowe prawo pracy [International labour law], t. 1: Międzynarodowe publiczne prawo pracy standardy międzynarodowe [International public labour law: International standards], Warszawa.

Świątkowski A. M. (2013) Gwarancje prawne pokoju społecznego w stosunkach pracy [Legal guarantees of social peace in labour relations], Warszawa. 
Unterschütz (2019) Partnerzy społeczni w Europejskim Filarze Praw Socjalnych: aktorzy czy statyści?, "Młody Jurysta," nr 2.

Witkowski J. (2014) Prawo pracodawców do lokautu [Employers' right to a lockout], "Roczniki Administracji i Prawa," nr 1.

\section{Internet sources}

Commission Staff Working Document Accompanying the document Communication from the Commission to the European Parliament, the Council and the European Economic and Social Committee Monitoring the implementation of the European Pillar of Social Rights $\{\mathrm{COM}(2018) 130 \mathrm{final}\}$, https://eur-lex.europa.eu/legal-content/SV/ TXT/?uri=SWD\%3A2018\%3A67\%3AFIN (access: 2 February 2019).

Commission Staff Working Document Accompanying the document Communication from the Commission to the European Parliament, the Council, the European and Social Committee and the Committee of the Regions Establishing a European Pillar of Social Rights $\{\mathrm{COM}(2017) 250$ final $\}\{\operatorname{SWD}(2017) 200$ final $\}$ SWD(2017) 206 final $\}$, https://eur-lex. europa.eu/legal-content/EN/TXT/?uri=CELEX\%3A52017SC0201 (access: 12 February 2019).

Commission Staff Working Document, Country Report Poland 2018, Accompanying the document: Communication from the Commission to the European Parliament, the Council, the European Central Bank and Eurogroup 2018 European Semester: Assessment of progress on structural reforms, prevention and correction of macroeconomic imbalances, and results of in-depth reviews under Regulation (EU) No. 1176/2011 \{COM(2018) 120 final\}, https://eur-lex.europa.eu/legal-content/EN/TXT/?uri=SWD:2018:219:FIN (access: 12 February 2019).

Draft Joint Employment Report from the Commission and the Council accompanying the Communication from the Commission on the Annual Growth Survey 2019, $\{\operatorname{COM}(2018)$ 761 final\}, https://eur-lex.europa.eu/legal-content/EN/TXT/?qid=1547650919951\&uri=C ELEX\%3A52018DC0761 (access: 20 January 2020).

De Schutter O. (2018) The European Pillar of Social Rights and the Role of the European Social Charter in the EU Legal Order, https://www.coe.int/en/web/european-social-charter/-/ study-on-the-european-pillar-of-social-rights-and-the-role-of-the-european-social-charter-in-the-european-union-legal-order (access: 10 December 2019).

ESCR Conclusions from the XX-3 session, United Kingdom, https://rm.coe.int/1680595c15 (access: 2 February 2019).

Explanations of the Praesidium of the Convention relating to the Charter of Fundamental Rights (2007/C 303/02), http://old.eur-lex.europa.eu/pl/Creatiwie/dat/32007X1214/htm/ C2007303PL.01001701.htm\#Note_E0001_expl (access: 2 February 2019).

Joint Employment Report as adopted by the EPSCO Council on 15 March 2018, https://ec.europa. eu/social/BlobServlet?docId=18624\&langId=en, https://ec.europa.eu/social/main.jsp?adv SearchKey=joint + employment + report $\&$ mode $=$ advancedSubmit $\&$ cat Id $=22 \&$ policyArea $=$ $0 \&$ policyAreaSub $=0 \&$ country $=0 \& y e a r=0$ (access: 2 February 2019). 
Monitoring EU Member States' Performance Under the European Pillar of Social Rights, https://ec.europa.eu/commission/sites/beta-political/files/social-scoreboard-2018-country-reports_en.pdf (access: 2 February 2019).

Report of the Committee of Experts on the Application of Conventions and Recommendations (Art. 19, 22 and 35 of the Constitution). Report III (Part 1A), https://www.ilo.org/public/ libdoc/ilo/P/09661/09661(2012-101-1A).pdf (access: 27 February 2019).

The Social Scoreboard, https://ec.europa.eu/social/main.jsp?langId=en\&catId=89\&newsId=9 163\&furtherNews=yes\&furtherNews=yes (access: 2 February 2019).

\section{Court sentences}

Judgment of the CJEU of 11 December 2007, C-438/05, International Transport Workers' Federation; Fininish Seamens's Union v. Viking Line ABP, OU Line Easti, ECR 2007 I-10779. Judgment of the CJEU of 18 December 2007, C-341/05, Laval Und Partneri Ltd v. Svenska Byggnadsarbetateforbundent, Svenska Byggnadsarbetateforbundet advelning 1, Byggettan, Svenska Elekrikerforbundet, ECR 2007 I-11767.

Judgment of the ECHR of 21 April 2009, Enerji Yap1-Yol Sen v. Turkey, application no. 68959/01. Judgment of the ECHR of 8 September 2014, National Union of Rail, Maritime and Transport Workers (RMT) v. the United Kingdom, application no. 31045/10.

Judgment of the ECHR of 27 November 2014, Hrvatski liječnički sindikat v. Croatia, application no. $36701 / 09$.

\section{Legal acts}

Convention No. 105 concerning the Abolition of Forced Labour, adopted in Geneva on 25 June 1957 by the General Conference of the International Labour Organization, Dz.U. of 14 July 1959, No. 39, item 240.

The Act of 23 May 1991 on the resolution of collective disputes, Dz.U. 2019, item 174 consolidated text.

The Constitution of the Republic of Poland of 2 April 1997, Dz.U. 1997, No. 78, item 483 as amended.

The Act of 18 September 2001-Maritime Code, Dz.U. 2018, item 2175 consolidated text. International Labour Office (2018) Freedom of Association: Compilation of decisions of the Committee on Freedom of Association, International Labour Office Geneva. 